\title{
Experimental arthritis of rabbits caused by intra-articular injection of autologous Fab2 produced by digestion of IgG with cathepsin D
}

\section{Microscopical and immunohistochemical findings in short-term experiments}

\author{
K.FEHR, M. VELVART, A. BÖNI, H.WATANABE, M. A.SPYCHER, ANDJ.R.RÜTTNER \\ From the University Department of Rheumatology and Pathological Anatomy, Cantonal Hospital, \\ Zurich, Switzerland
}

\begin{abstract}
Fehr, K., Velvart, M., Böni, A., Watanabe, H., Spycher, M. A., and Rüttner, J. R. (1976). Annals of the Rheumatic Diseases, 35, 85-96. Experimental arthritis of rabbits caused by intra-articular injection of autologous Fab2 produced by digestion of IgG with cathepsin D. I. Microscopical and immunohistochemical findings in short-term experiments. Intra-articularly injected autologous Fab2 produced from IgG by homologous cathepsin $\mathbf{D}$ induces in animals not given prior immunization acute synovitis after 1 and 3 injections, acute synovitis after 6 injections, and chronic synovitis after 12 injections. Histologically, the chronic synovitis is similar to synovitis in rheumatoid arthritis (RA). In the joint, cathepsin D Fab2 appears to act as a fairly strong antigen. Evidence for this is provided by the infiltration of large numbers of polymorphonuclear leucocytes, the marked phagocytic activity of the exudate leucocytes and tissue phagocytes, and the stimulation of the synthesis of specific antibodies (homoreactants) in the synovial plasma cells. The immediate action of injected Fab2 suggests that it forms biologically active immune complexes with homoreactants already present. These complexes are phagocytosed, the homoreactants being demonstrable immunohistochemically in inclusions of the exudate and tissue phagocytes. In addition, the local synthesis of antigammaglobulins of rheumatoid factor type is also induced. These react with heat-aggregated homologous as well as human IgG and are likewise found in inclusions in the exudate and tissue phagocytes. In the serum of the animals the titre of rheumatoid factor-like antigammaglobulins increases to an extent depending on the number of injections given. These histochemical and serological findings show striking parallels with the findings in human RA.
\end{abstract}

In man and animals proteolysis of IgG results in the unmasking of antigenic structures not detectable in the intact molecule (Litwin, 1968; Mandy, 1966a, b, 1967; Mandy, Woolsey and Lewis, 1968; Osterland, Harboe, and Kunkel, 1966; Waller and Blaylock, 1966). The unmasked antigens react with nonprecipitating antibodies which are demonstrable by suitable techniques in almost all human and animal sera (Natvig, 1966; Mandy, 1967). These antibodies are known in man as agglutinators (Osterland and others, 1966), in rabbits as homoreactants (Mandy and Lewis, 1966). The frequency of their occurrence indicates that they belong to a population of natural antibodies. Their origin may have something to do with the 
physiological catabolism of IgG and the breakdown of immune complexes containing IgG. Their physiological significance is, however, unknown. In a number of studies (Fehr and LoSpalluto, 1971; Mandy, 1967; Waller and Blaylock, 1966) it has been clearly shown that specific proteases unmask specific antigens that are recognized by specific antibodies.

Attention was first drawn to the pathophysiological activity of agglutinators by Quismorio and others (1968), who observed arthritis flares in both rheumatoid arthritis (RA) patients and healthy subjects after the intra-articular injection of papain Fab. Rawson, Quismorio, and Abelson (1969) studied the inflammatory effect of IgG fragments in animals and found that intra-articular injection of papain Fab into rabbits without serum homoreactants at first caused no synovitis. The injections caused the formation of serologically demonstrable homoreactants to papain Fab. These fragments, whether of homologous or autologous origin, then brought about synovitis. Repeated injections led to chronic synovitis.

From these experiments it seems that autologous IgG fragments are antigens which under suitable conditions, i.e. in the presence of specific antibodies and of a sufficiency of fragments at suitable sites such as joints, bring about or modify inflammatory processes. It follows that activated endogenous proteases could in this way have an inflammatory action. In order to test this hypothesis, Rawson's arthritis was reproduced by means of IgG fragments that were possibly of endogenous origin.

The enzyme used for breaking down IgG was cathepsin $\mathrm{D}$, a widely distributed protease occurring also in the cells of the joints (Watanabe and others, 1976; Weston, 1969). According to Fehr, LoSpalluto, and Ziff (1970), it breaks down IgG mainly to Fab2, whose antigenic determinants are clearly distinguishable from those of pepsin $F\left(a b^{\prime}\right) 2$ (Fehr and LoSpalluto, 1971). Preliminary tests with intraarticularly injected homologous cathepsin D Fab2 showed that the resulting synovitis was accompanied by the formation of rheumatoid factor (RF) (Fehr, Velvart, and Böni, 1974). This paper will describe in detail the effect of short-term intra-articular injection of autologous cathepsin D Fab2 in rabbits (for preliminary findings see Fehr, 1971). The histological and immunological changes will be analysed, and it will be shown that a possible action of endotoxin-like substances or other toxins, as well as injuries to the joint, can be excluded. In addition, the direct effect on the joint of small amounts of the homologous cathepsin D used to break down IgG will be described.

\section{Materials and methods}

EXPERIMENTAL ANIMALS

White Kunath rabbits weighing 2-3 kg were used. They were maintained on a standard Nafag (Gossau, $\mathrm{CH}$ ) diet with water, and kept in air-conditioned, nonsterile rooms with artificial lighting.

ISOLATION OF IgG

Autologous IgG was precipitated from the serum by $50 \%$ ammonium sulphate solution and chromatographed on DEAE cellulose (SERVA AG, Heidelberg, GFR, capac. 0.62 ) using $0.01 \mathrm{~mol} / 1$ phosphate buffer of $\mathrm{pH} 7.4$ in the presence of $0.04 \%$ sodium azide. The first two-thirds of the first peak were used. The purity of the eluted IgG was verified by Ouchterlony analysis. The isolated IgG was concentrated to $20 \mathrm{mg} / \mathrm{ml}$ in an Amicon ultrafiltration apparatus, freed from buffer by a large excess of $0.15 \mathrm{~mol} / 1 \mathrm{NaCl}$ in the presence of $0.04 \%$ sodium azide, filtered sterile through millipore membranes, and stored at $-20^{\circ} \mathrm{C}$.

ISOLATION OF PARTIALLY PURIFIED CATHEPSIN D Partially purified cathepsin D was prepared from homologous rabbit liver and spleen by Barret's method (1967), filtered sterile, and stored at $-60^{\circ} \mathrm{C}$. The activity of the product was determined with rabbit fraction II by the method of Fehr and others (1970), its protein concentration turbidimetrically with sulphosalicylic acid at $680 \mathrm{~nm}$ by the method of Henry (1974).

PREPARATION AND PURIFICATION OF IgG FRAGMENTS

$100 \mathrm{mg}$ autologous IgG in $5 \mathrm{ml} 0.15 \mathrm{~mol} / 1 \mathrm{NaCl}$ and $0.04 \%$ sodium azide was incubated with $1 \mathrm{ml}$ partially purified cathepsin $\mathrm{D}$ (corresponding to a protein content of $1 \mathrm{mg} /$ $\mathrm{ml}$ ) for $48 \mathrm{~h}$ at $\mathrm{pH} 3.2$ and $37^{\circ} \mathrm{C}$. The $\mathrm{pH}$ of the mixture was checked at regular intervals and adjusted if necessary. Proteolysis was stopped by normalizing the $\mathrm{pH}$ to $7 \cdot 4$ and the proteolysate chromatographed on Biogel $A$ $1.5 \mathrm{~mol} / 1$ using $0.05 \mathrm{~mol} / 1$ TRIS buffer at $\mathrm{pH} 7.4$ containing $0.2 \mathrm{~mol} / 1 \mathrm{NaCl}$ and $0.04 \%$ sodium azide (Fehr and others, 1970). Ouchterlony analysis of the main peak showed (Fig. 1) that practically all the IgG had been broken down to Fab2 or smaller fragments. Residual IgG and fragments smaller than Fab2 were eliminated by rechromatography of the first half of the peak on Biogel A $1.5 \mathrm{~mol} / \mathrm{l}$ and of the second half on Sephadex G-100. In some of the experiments the middle two-thirds of the peak was rechromatographed on Sephadex G-150. The Fab2 fragments obtained in this way were pooled and reduced to $1 \mathrm{mg} / \mathrm{ml}$ after rinsing in an Amicon ultracentrifugation apparatus with a large excess of pyrogen-free $0.15 \mathrm{~mol} / 1$ $\mathrm{NaCl}$. The protein concentration of this $\mathrm{Fab} 2$ was determined spectrometrically at $280 \mathrm{~nm}$ assuming an extinction of $E(1 \% / 1 \mathrm{~cm})=13$, its purity by Ouchterlony analysis. The molecular weight of the fragments was estimated by gel chromatography in a calibrated Sephadex G-200 column by the method of Andrews (1965), rabbit IgG, human serum albumin (Behring AG, Marburg, GFR), ovalbumin (Sigma Chem., St. Louis, Mo., USA), and myoglobin (Fluka AG, Buchs, CH) being used for calibration. The Fab2 fragments were compared with pepsin $F\left(a b^{\prime}\right) 2$ in an analytical Spinco centrifuge Model E at 56600 r.p.m. in physiological saline. Finally the isolated Fab2 fragments were filtered sterile and stored in $0.5 \mathrm{ml}$ portions at $-20^{\circ} \mathrm{C}$.

CONTROL SOLUTIONS

These consisted of (1) pyrogen-free $0.15 \mathrm{~mol} / 1 \mathrm{NaCl}$ solution; (2) TRIS buffer from the last chromatographic 


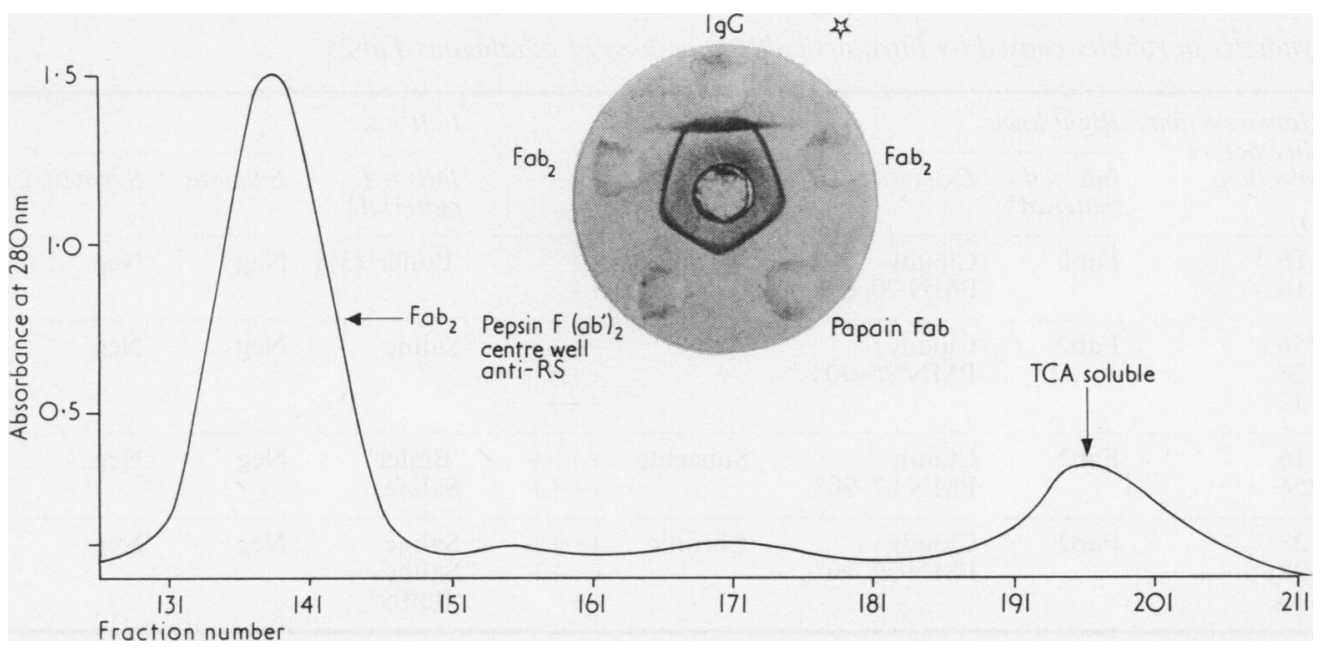

FIG. 1 Fractionation of a digest of $100 \mathrm{mg}$ rabbit IgG by $1 \mathrm{mg}$ rabbit cathepsin D at pH 3.2. Gel filtration through biogel A 1, 5 molll in 0.05 molll TRIS, 0.2 mol/l $\mathrm{NaCl}$ pH 7.4 containing $0.04 \% \mathrm{NaN}_{3}$. IgG is mainly broken down to Fab2 fragments.* Pattern of immunoprecipitation of Fab2 from rabbit IgG digested with homologous cathepsin $D$ (upper side wells). Centre well contains goat antirabbit serum. Complete identity with $F\left(a b^{\prime}\right) 2$ and Fab produced by pepsin and papain digestion of rabbit IgG respectively. Partial identity with original rabbit IgG

column (for Fab2 purification) after rinsing in an Amicon ultrafiltration apparatus with a large excess of pyrogenfree $0.15 \mathrm{~mol} / 1 \mathrm{NaCl} ;$ (3) partially purified cathepsin $\mathrm{D}$ at a concentration of $12 \mu \mathrm{g} / \mathrm{ml}$ in pyrogen-free $0.15 \mathrm{~mol} / \mathrm{l}$ $\mathrm{NaCl}$. The last two solutions were filtered sterile through a millipore filter and stored in $0.5 \mathrm{ml}$ portions at $-20^{\circ} \mathrm{C}$.

\section{STERILITY TESTS AND CONTROLS}

All buffer solutions used in gel chromatography as well as the pyrogen-free $\mathrm{NaCl}$ solution were autoclaved in sterile bottles. The chromatographic columns and tubing were disinfected before use with Merfen. The DEAE cellulose was disinfected by boiling, the Biogel and Sephadex by means of $0.01 \%$ diethyl carbonate solution added to the TRIS buffer. The cathepsin D, IgG, and their mixtures, before and after incubation, and the chromatographically separated Fab2 fragments were filtered sterile through millipore filters and subjected to microbiological control. The Amicon ultrafiltration apparatus was disinfected before use with $70 \%$ alcohol.

\section{ANTISERA}

In the Ouchterlony analysis, use was made of commercial antisera to rabbit IgG and to rabbit total gammaglobulin (supplied by Hyland, California, USA).

\section{INTRA-ARTICULAR INJECTIONS}

The injections were given 3 times weekly, the number of intra-articular injections being 1, 3,6, and 12. Each of a group of 10 rabbits received $0.5 \mathrm{mg} \mathrm{Fab2}$ in $0.5 \mathrm{ml}$ physiological saline in the right knee and $0.5 \mathrm{ml}$ saline or ultrafiltered buffer in the left knee joint (Table I). 8 rabbits received a corresponding number of $6 \mu \mathrm{g}$ injections of cathepsin D preparation in $0.5 \mathrm{ml}$ physiological saline in the right knee and $0.5 \mathrm{ml}$ physiological saline in the left knee (Table III). The amount of cathepsin D injected was determined by TCA tests using the chromatographically purified Fab2 preparation and IgG, the assumption being that cathepsin D breaks down Fab2 only slowly but Fc rapidly. The very small degree of proteolysis observed, lying almost within the limits of error of the method, were regarded as possible evidence of the presence of cathepsin D traces in the Fab2.

The intra-articular injections were given laterally in the subpatellar joint space using intradermal needles under sterile conditions in a nonaseptic laboratory.

\section{OPERATIVE TECHNIQUE}

$24 \mathrm{hr}$ after the last injection the rabbits were anaesthetized with Hypnorm-Nembutal, bled about $50 \%$ by puncture of the auricular vein, and the joint opened up under sterile conditions in a nonaseptic laboratory. One part of the joint exudate was set aside for sterility tests. Microbiological tests of the articular puncture fluid in no case gave positive results.*

After macroscopical examination, the joints were synovectomized, articular tissue being taken from the superior and posterior recesses for histological and immunohistochemical examination. The patella and medial part of the femoral head were removed for histological examination of the cartilage.

\section{HISTOLOGICAL EXAMINATION}

The articular puncture fluid was removed as far as possible with a Record syringe, mixed with liquemin and hyaluronidase (Cilag Chemie AG, Schaffhausen, $\mathrm{CH}$ ) and subjected where possible to a cell count by means of a Coulter counter. Smears of the sediment were stained by the MayGrünwald method, air-dried for immunohistochemical examination, and stored at $-60^{\circ} \mathrm{C}$.

* Sterility tests were carried out in the Department of Microbiology, University of Zurich. 
Table I Synovitis in rabbits caused by intra-articular injections of autologous Fab2*

\begin{tabular}{|c|c|c|c|c|c|c|c|c|}
\hline \multirow{2}{*}{$\begin{array}{l}\text { No. of } \\
\text { injections }\end{array}$} & \multirow{2}{*}{$\begin{array}{l}\text { Homoreactant } \\
\text { titre before } \\
\text { injections }\end{array}$} & \multicolumn{4}{|c|}{ Right knee } & \multicolumn{3}{|l|}{ Left knee } \\
\hline & & $\begin{array}{l}\text { Injected } \\
\text { material } \uparrow\end{array}$ & Exudate & Synovitisł & & $\begin{array}{l}\text { Injected } \\
\text { material } \dagger\end{array}$ & Exudate & Synovitis \\
\hline $\begin{array}{l}1 \\
1\end{array}$ & $\begin{array}{l}16 \\
16\end{array}$ & Fab2 & $\begin{array}{l}\text { Cloudy } \\
\text { PMN 70-90\% }\end{array}$ & Acute & $\begin{array}{l}++ \\
++\end{array}$ & 'Buffer' (3)§ & Neg & Neg \\
\hline $\begin{array}{l}3 \\
3 \\
3\end{array}$ & $\begin{array}{r}256 \\
128 \\
32\end{array}$ & Fab2 & $\begin{array}{l}\text { Cloudy } \\
\text { PMN 85-90\% }\end{array}$ & Acute & $\begin{array}{l}+++ \\
+++ \\
+++\end{array}$ & Saline & $\overline{\mathrm{Neg}}$ & $\overline{\mathrm{Neg}}$ \\
\hline $\begin{array}{l}6 \\
6\end{array}$ & $\begin{array}{r}16 \\
256\end{array}$ & Fab2 & $\begin{array}{l}\text { Cloudy } \\
\text { PMN 87-90\% }\end{array}$ & Subacute & $\begin{array}{l}++++ \\
++++\end{array}$ & $\begin{array}{l}\text { 'Buffer' } \\
\text { Saline }\end{array}$ & $\mathrm{Neg}$ & $\mathrm{Neg}$ \\
\hline $\begin{array}{l}12 \\
12 \\
12\end{array}$ & $\begin{array}{r}128 \\
128 \\
16\end{array}$ & Fab2 & $\begin{array}{l}\text { Cloudy } \\
\text { PMN 59-90\% }\end{array}$ & Chronic & $\begin{array}{l}+++t \\
+++t \\
++\end{array}$ & $\begin{array}{l}\text { Saline } \\
\text { Saline } \\
\text { 'Buffer' }\end{array}$ & Neg & Neg \\
\hline
\end{tabular}

* Fab2 produced by proteolysis of IgG with homologous cathepsin D.

$+0.5 \mathrm{ml}$ per injection.

$\$$ Scoring method explained in text.

8 This rabbit received 3 injections into the left (control) joint.

PMN, polymorphonuclear leucocyte.

The capsular tissue was deep-frozen in isopenthan and liquid nitrogen for immunohistochemical examination and stored at $-60^{\circ} \mathrm{C}$. For the histological examination the same material was fixed in neutral buffered formalin (pH 7.4) and embedded in Paraplast. Sections $5 \mu \mathrm{m}$ thick were cut from both these preparations and stained with haemalum and van Gieson's stain. Bone from the area of the joint was fixed with neutralized formalin containing cetylpyridine, decalcified with $5 \%$ nitricacidandembedded in Paraplast. Sections of 6-10 $\mu \mathrm{m}$ were then cut.

\section{IMMUNOHISTOCHEMICAL EXAMINATION}

Smears of the joint exudate sediment were fixed with glacial acetic acid/alcohol for $15 \mathrm{~min}$ at $-20^{\circ} \mathrm{C}$, the tissue sections with $96 \%$ alcohol under the same conditions.

FITC-labelled goat antirabbit IgG (Miles Corp., Kankakee, Ill., USA) was used as antiserum, TRITClabelled bovine serum albumin as background. Chromatographically purified rabbit and human IgG and homologous cathepsin D Fab2 were labelled with FITC (BBL, Cockeysville, Md., USA) by the method of Brandtzaeg (1973a, b) and Hijmans, Schuit, and Klein (1969). The F/P ratio was between $2 \cdot 2$ and $5.6 \mu \mathrm{g} / \mathrm{mg}$. The labelled homologous and heterologous IgG was heat-aggregated at $63^{\circ} \mathrm{C}$ at a concentration of about $1 \mathrm{mg} / \mathrm{ml}$ for $10 \mathrm{~min}$ and centrifuged for $30 \mathrm{~min}$ at 11000 r.p.m. The immunofluorescence examination was made by the method of Hijmans and others (1969).

The Zeiss microscope was used with an incident-light condenser III-RS. For FITC this was fitted with an FL 500 reflector, a $2 \times$ BG $12 / 3 \mathrm{~mm}, \mathrm{Kp} 500$, and a suppression filter 50. For TRITC an FL 580 reflector, FL 546, Kp 630 and suppression filter 58 were used.

\section{HAEMAGGLUTINATION TESTS}

Homoreactants were titrated out by the method of Fehr and LoSpalluto (1971) using sheep erythrocytes sensitized with rabbit antisheep erythrocyte cathepsin D Fab2 from IgG. Antigammaglobulins were titrated out with sheep erythrocytes or $\mathbf{O} \mathbf{R h}+$ human erythrocytes sensitized with rabbit antisheep erythrocyte IgG or antiCD Ripley IgG.* In both cases appropriate controls were carried out.

\section{Results}

CharaCterization OF INJECTED Fab2 FRAGMENTS

$100 \mathrm{mg}$ of rabbit IgG was broken down almost completely by $1 \mathrm{mg}$ enzyme protein from homologous cathepsin $\mathbf{D}$ under the conditions described above (see Materials and methods). The principal fragment was Fab2 with a molecular weight by gel chromatography of 100000 (Fig. 1). Ouchterlony analysis showed this fragment to be completely identical with pepsin $F\left(a b^{\prime}\right) 2$ and papain $F a b$, and partially identical with IgG (Fig. 1). In analytical ultracentrifuging with double cells it has the same velocity of migration as pepsin $\mathrm{F}\left(\mathrm{ab}^{\prime}\right) 2$ (Fehr, 1971). On the other hand, the proteolytically unmasked antigenic determinants of the fragment were clearly different from those of pepsin $F\left(a b^{\prime}\right) 2$ and papain $F a b$ (details to be published).

EFFECT OF INTRA-ARTICULAR INJECTIONS OF AUTOLOGOUS Fab2

As shown in Table $I$, the animals received 1-12 injections of Fab2 in the right knee and physiological saline or ultrafiltrated buffer in the left knee. Before injection, each animal was shown to possess specific serum homoreactants to the injected Fab2 fragment. The titres varied between 1:16 and 1:256 (Table I). All the joints into which Fab2 was injected exhibited a cloudy exudate of low viscosity. Because of the * Serum Ripley was kindly supplied by Dr. M. Waller, Richmond, Va., USA. 
intravital opening-up of the joints under narcosis, the bleeding in some cases prevented a cell count being made. Those made ranged between 19500 and 41000 , usually with $70-90 \%$ polymorphonuclear leucocytes (PMNs) (Table I). Apart from marked signs of degeneration, up to $90 \%$ had a phagocytic appearance and contained eosinophilic, granular material. Many exudate macrophages showed phagocytosis of degenerating PMNs. A small proportion of the mononuclear cells were small lymphocytes.

Macroscopically, all the joints displayed hyperaemia of the synovial membrane and, after 12 injections, marked swelling and some formation of villi.

Quantification of the histological findings in the synovial membrane (Table I) was based on the following scores.

Acute synovitis: pure infiltration of PMNs.

Subacute synovitis: infiltration predominantly with PMNs with a few mononuclear cells.

Chronic synovitis: infiltration predominantly with mononuclear cells, with rare focal infiltrations of PMNs. $++=$ focal, predominantly superficial infiltration; $+++=$ involvement of extensive areas of the synovial surface and of deeper layers; $++++=$ dense infiltration extending to deep layers and involving almost the whole of the membrane.

Table I shows that the animals exhibited acute synovitis after 1-3 injections (Fig. 2), subacute synovitis after 6 injections, and chronic synovitis after 12 injections. The infiltrating PMNs mostly contained eosinophilic material and showed frequent signs of degeneration. In all cases the tissue displayed oedematous loosening. After 3 injections layers of fibrinoid material were observed over the

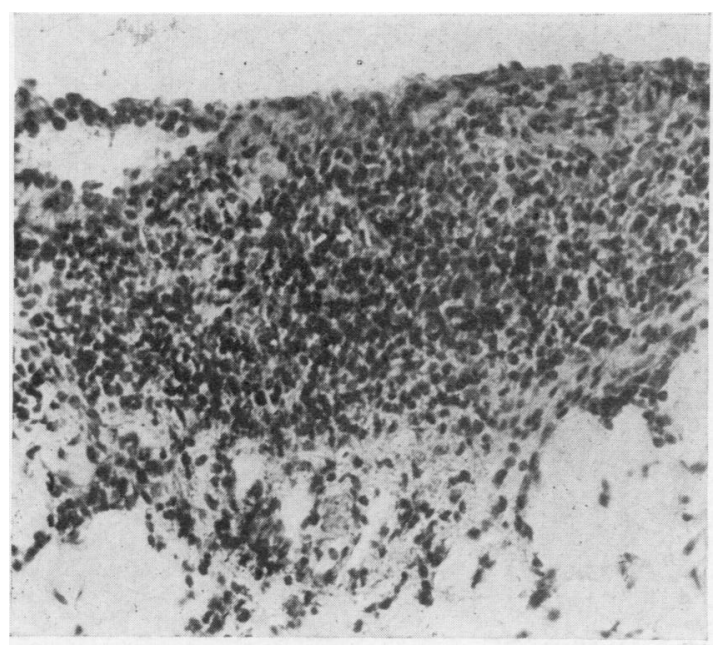

FIG. 2 Acute synovitis in a rabbit after 3 intra-articular injections of autologous Fab2 produced by homologous cathepsin D. Dense infiltrate with PMNs showing signs of degeneration. Haemalum. $\times 100$ lining layer. After 6 and 12 injections these deposits were increasingly in evidence and extended as far as the subsynovial layer. After 12 injections the lining layer showed patchy necrosis. These areas were marked by the presence of fibrinoid material (Fig. $3 a$ ) and in some places by fibroblasts. Histologically, formation of villi was observed at the earliest after 6 and 12 injections. No changes in the lining layer were observed after 1 injection. After 3 injections it showed moderate hyperplasia with a maximum of 3 to 4 cell layers. After 6 and 12 injections the hyperplasia extended over wide areas and was about 6 cells thick, these cells displaying swelling of cubic type (Fig. 3b). The capillaries and venules were

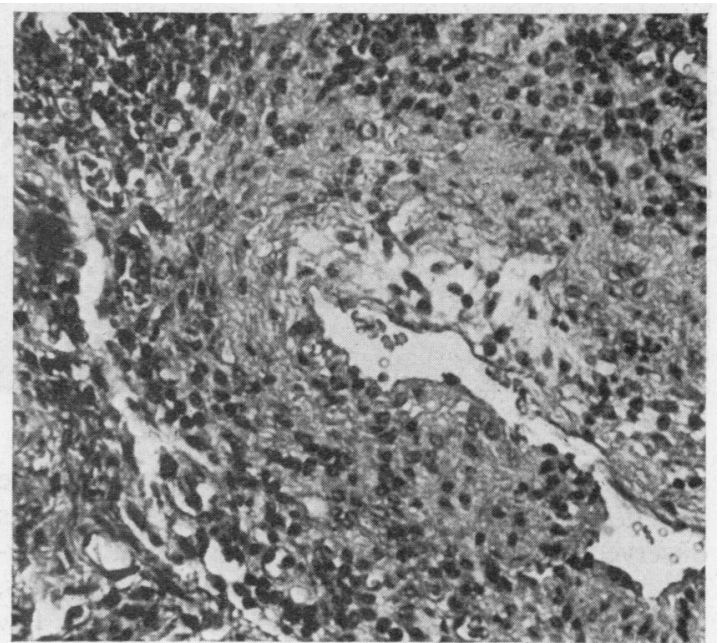

$a$

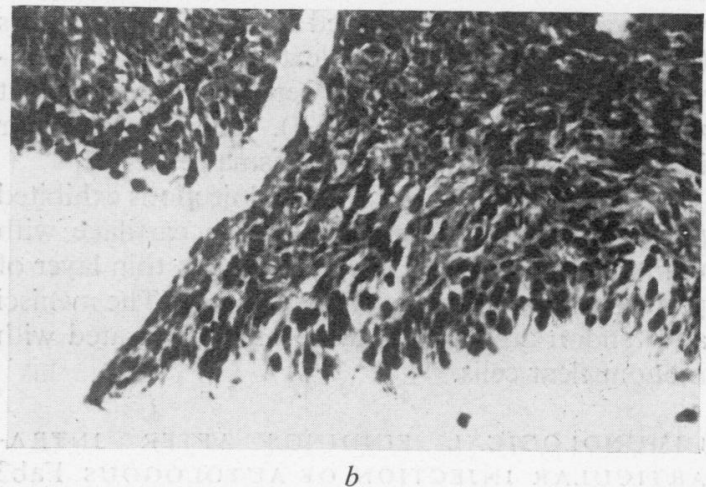

FIG. 3 (a) Chronic synovitis in a rabbit after 12 intraarticular injections of autologous Fab2 produced by homologous cathepsin D. Superficial exudation of fibrinoid material showing some invasion by fibroblasts and lining layer with patchy necrosis. Dilated capillaries in the sublining layer. (b) Subacute synovitis in a rabbit after 6 intra-articular injections of autologous Fab2 produced by homologous cathepsin D. Hyperplastic lining layer with elongated swollen lining cells. van Gieson. $\times 170$ 


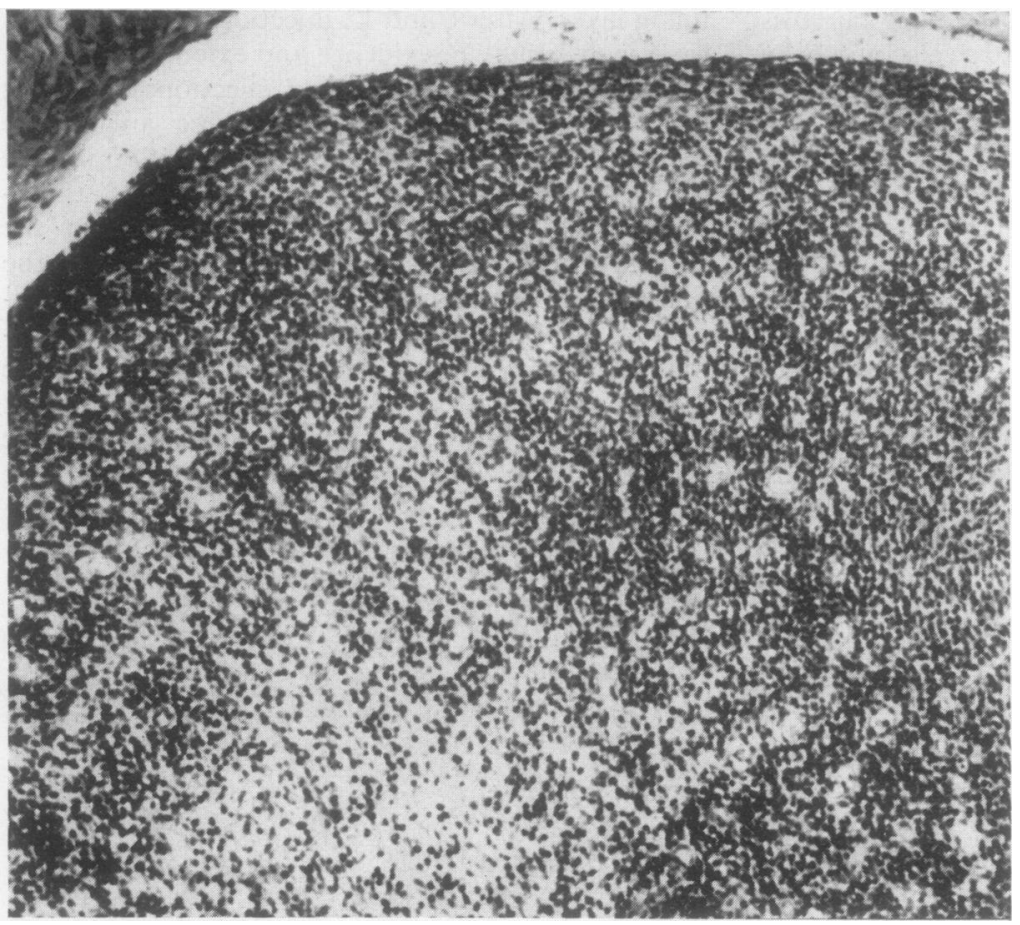

FIG. 4 Chronic synovitis after 12 intra-articular injections of autologous Fab2 produced by homologous cathepsin D. Extensive diffuse mononuclear infiltrate with moderate subsynovial exudate of fibrinoid material and dilated capillaries. Haemalum. $\times 95$

already dilated after 3 injections. After 6 or more injections thrombosis of arteries and arterioles was observed. After 6 injections, perivascular roundcell infiltrations containing small lymphocytes, medium to large mononuclear cells, and a few plasma cells were observed. After 12 injections these mononuclear infiltrations covered the whole synovial membrane and extended into the deeper layers (Fig. 4). Richly mononuclear and in part perivascular round-cell follicles were also observed, but no germinal centres (Fig. 5). The mononuclear infiltrations contained many plasma cells.

The animals which received 12 injections exhibited patchy, superficial loosening of the cartilage with unmasking of the fibrils and, in part, a thin layer of pannus over some parts of the cartilage. The menisci and tendon attachments were often infiltrated with mononuclear cells.

IMMUNOLOGICAL FINDINGS AFTER INTRAARTICULAR INJECTION OF AUTOLOGOUS Fab2 Before and after the intra-articular injections, the serum of the animals was examined in respect of the titre of homoreactants and the presence of RFtype antibodies. In none of the animals, some of which received 12 injections, was any significant increase in homoreactants ( $>\log 2$ titre steps) found in comparison with the initial value. Likewise no serologically RF-type antibodies to homologous IgG could be shown. On the other hand, in the heterologous system in which anti-CD Ripleysensitized human $\mathbf{O} R \mathbf{R h}+$ erythrocytes were used, the formation of RF-type antibodies could be clearly shown (Fig. 6). The serum titre of these antibodies was dependent on the number of intra-articular Fab2 injections given, with a borderline titre after

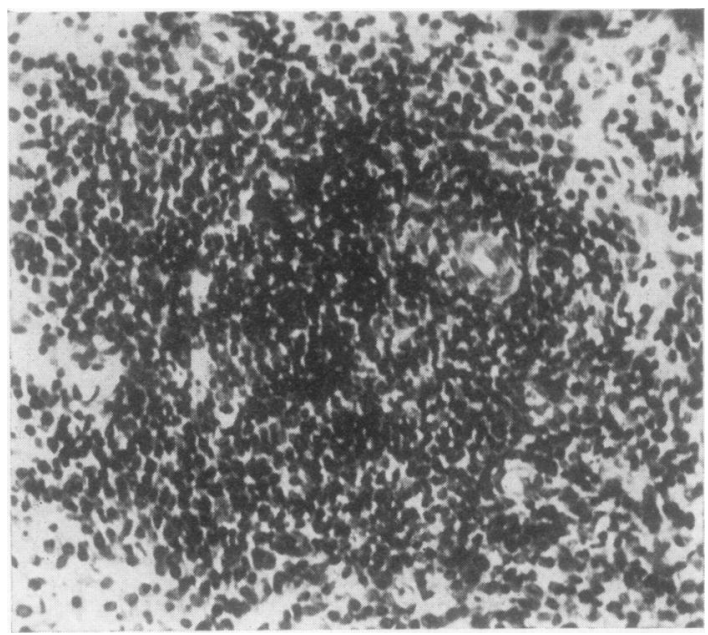

FIG. 5 Chronic synovitis after 12 intra-articular injections of autologous Fab2 produced by homologous cathepsin D. Note a dense focal perivascular mononuclear cell aggregation. Haemalum. $\times 93$ 


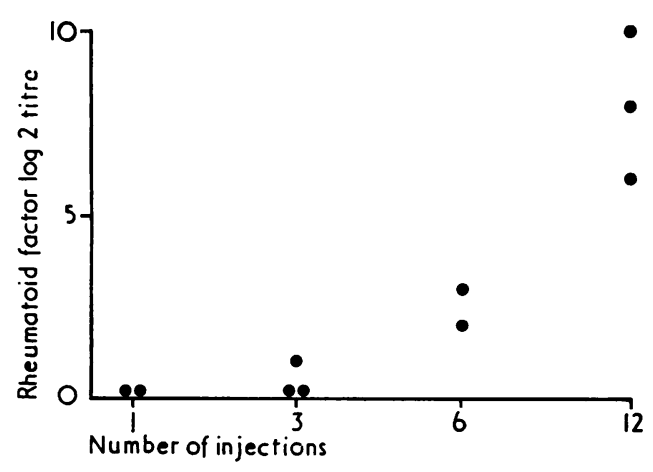

FIG. 6 Occurrence of serum 'rheumatoid factor' after intra-articular injections of autologous Fab2 in the rabbit. Fab2 was produced by proteolysis of $\operatorname{IgG}$ with homologous cathepsin D

3 and 6 injections (applied over a period of 1-2 weeks) and a high titre after 12 injections.

Since the microscopical finding of RA cells and/or PMNs containing eosinophilic material in the synovial fluid and membrane pointed to active phagocytosis, it was decided to search for phagocytosed homoreactants or 'RF' using FITC-labelled Fab2 and homologous as well as heterologous aggregated IgG. It was also important to know whether plasma cells or their precursors in the synovial membrane synthesized these two kinds of anti-IgG antibodies. Table II shows that homoreactants were present after 1 injection in inclusions in the region of the lining layer and after 3 or more injections in PMN inclusions of the exudate and in the tissue phagocytes (Fig. 7). These tissue phagocytes were mostly mononuclear, rarely polymorphonuclear. The findings in Table II in respect of 'RF' were even more in evidence when heat-aggregated rabbit IgG labelled with FITC was used. Inclusions containing 'RF' were consistently found in the exudate PMNs and in tissue phagocytes after 6 or more injections (Fig. 7). Inclusions containing 'RF' were found in the tissue and lining-layer phagocytes after 1 injection in one animal which was given 50 times Fab2 subcutaneously before the intra-articular injection. This animal had a serum 'RF' titre of 1:32 with heterologous IgG. Synthesis of homoreactants and 'RF' in the synovial membrane by plasma cells was clearly demonstrable after 12 Fab2 injections (Fig. 8, Table II).

EFFECT OF INTRA-ARTICULAR CONTROL INJECTIONS

As shown in Tables I and III, injections of $0.5 \mathrm{ml}$ pyrogen-free physiological saline or ultrafiltered buffer resulted in neither articular exudation nor synovitis. In some animals a few mononuclear infiltration cells were observed, but these could be interpreted as normal background. Marked reactions were seen in occasional animals given small injections of cathepsin D (and therefore included in Table III). The amount of partially purified cathepsin D preparation injected was $6 \mu \mathrm{g}$ per injection and was calculated as described above. From Table III it will be seen that patchy, superficial infiltrations of PMNs occurred in the one animal given 6 injections and in the two given 12 injections. In the latter two animals a few mononuclear infiltration cells were also observed. In no case was there any sign of changes in the lining layer or blood vessels, of oedema, or of exudate containing protein. In the immunological examination one of the animals with 12 injections had a serum 'RF' titre of $1: 128$ against heterologous IgG. In the smal

Table II Immunohistochemical findings after intra-articular injections of autologous Fab2 in the rabbit *

\begin{tabular}{|c|c|c|c|c|c|c|c|c|}
\hline \multirow{4}{*}{$\begin{array}{l}\text { No. of } \\
\text { injections }\end{array}$} & \multirow{2}{*}{\multicolumn{2}{|c|}{$\begin{array}{l}\text { Exudate: inclusions in } \\
P M N \text { and macrophages }\end{array}$}} & \multicolumn{6}{|l|}{ Synovium } \\
\hline & & & \multicolumn{4}{|l|}{ Inclusions in: } & \multirow{2}{*}{\multicolumn{2}{|c|}{$\begin{array}{l}\text { Production by } \\
\text { plasma cells }\end{array}$}} \\
\hline & \multirow{2}{*}{ Homoreactant $\dagger$} & \multirow{2}{*}{$R F_{+}^{+}$} & \multicolumn{2}{|l|}{ Lining cells } & \multicolumn{2}{|c|}{ Tissue phagocytes } & & \\
\hline & & & Homoreactant & $R F$ & Homoreactant & $R F$ & Homoreactant & $R F$ \\
\hline 1 & - & $(+) \S$ & + & + & - & - & - & - \\
\hline 3 & + & - & - & & - & + & - & - \\
\hline 3 & n.d. & - & - & & + & - & - & - \\
\hline 3 & n.d. & $(+)$ & - & & + & - & - & - \\
\hline 6 & - & ++ & - & & + & ++ & - & - \\
\hline 6 & - & ++ & - & & + & + & - & $(+)$ \\
\hline 12 & n.d. & n.d. & - & & + & + & + & + \\
\hline 12 & ++ & ++ & - & & ++ & ++ & ++ & ++ \\
\hline 12 & ++ & ++ & - & & ++ & ++ & ++ & ++ \\
\hline
\end{tabular}

$*(+)=$ single cells in the whole tissue; $+=1-2$ cells per high power field $1: 500 ;++=$ multiple cells per high power field.

+ Staining by FITC-labelled Fab2, counterstained with TRITC-labelled BSA.

₹ Staining by FITC-labelled heat aggregated homologous IgG. RF=rheumatoid factor.

$\$$ Confirmed by staining with FITC-labelled heat aggregated human IgG. This rabbit received 50 s.c. injections of Fab2 before intra-articular injection and exhibited serum RF. 




FIG 7 Left: Binding of FITC-labelled homologous Fab2 to synovial exudate leucocyte inclusions. Right: Binding of FITC-labelled heat aggregated IgG to synovial exudate leucocyte inclusions. Double staining with TRITC-labelled albumin was negative. $\times 500$

amount of exudate occurring in this animal, PMN inclusions containing 'RF' and homoreactant could be shown. Similar findings were made in another animal after 6 injections. Both the animals given 12 injections had inclusions containing homoreactant and 'RF' in a few phagocytic cells of the synovial membrane.

\section{Discussion}

Our experiments show that large amounts of autologous IgG fragments produced by the action of endogenous protease have an inflammatory effect when injected into the joint cavity and that repeated injections of this kind result in chronic synovitis. These findings with cathepsin D Fab2 fragments confirm those of Rawson and others (1969) with papain Fab. The results of our control experiments exclude the possibility that the observed effects were attributable to joint injury caused by

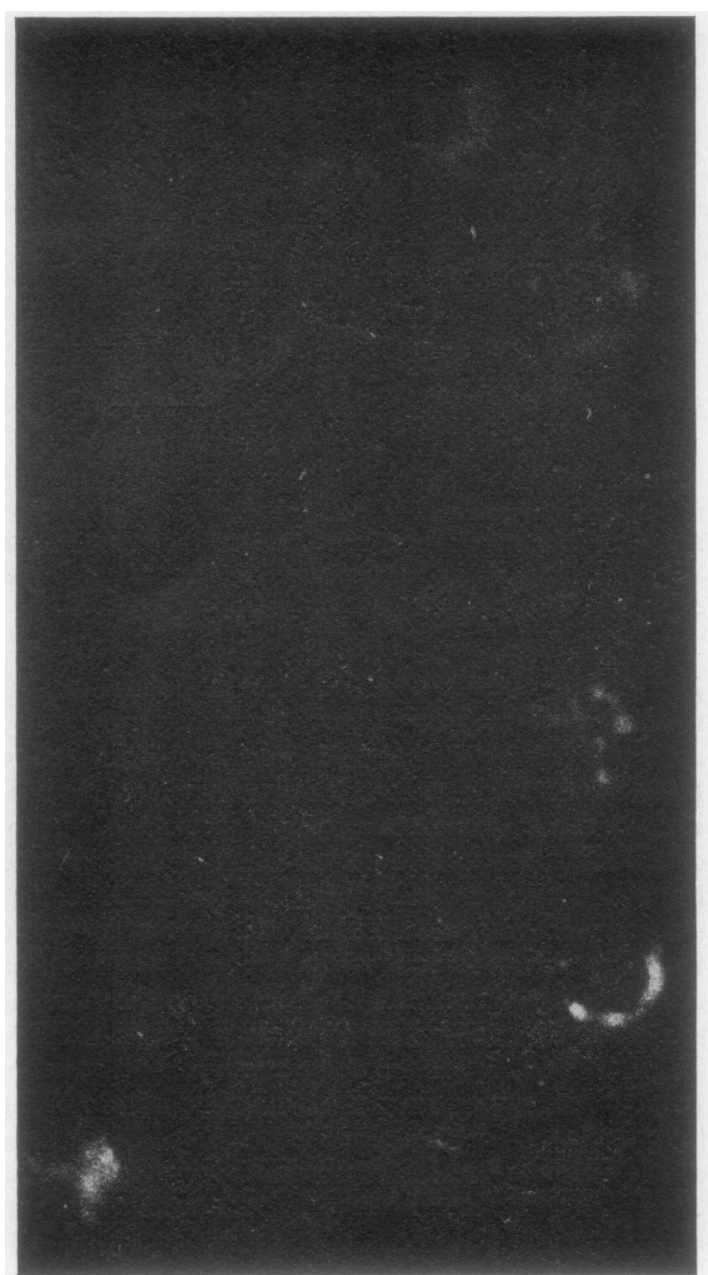

repeated injections, to endotoxin-like substances, or to residues of other toxic agents such as the sodium azide from the buffer solutions used in the chromatographic purification process. The control experiments also show that although the small amounts of cathepsin D used to break down IgG had a slight effect in some animals, this cannot be implicated in the massive changes seen in the synovial membrane. The mechanism of this cathepsin D effect is currently being investigated in our laboratory.

From the first intra-articular injection on, autologous Fab2 causes infiltration into the joint of large numbers of mainly PMNs. Under the conditions of our experiments, these cells constitute throughout the overwhelming majority of the exudate cells (Table I); this has also been shown to be the case in long-term studies (Velvart and others, 1976b). After 1 injection, and even more so after 3 injections, the synovial membrane shows all 

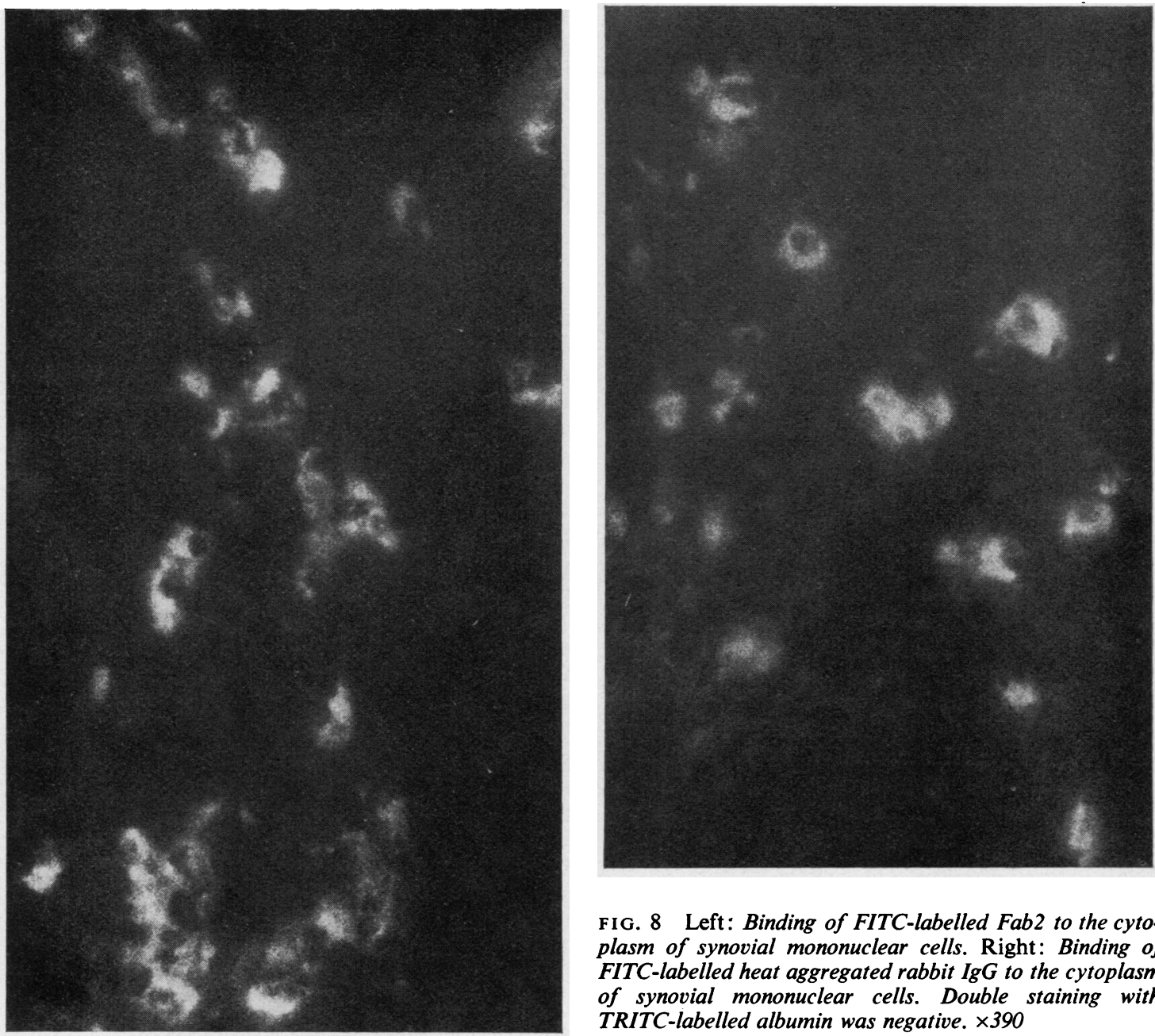

FIG. 8 Left: Binding of FITC-labelled Fab2 to the cytoplasm of synovial mononuclear cells. Right: Binding of FITC-labelled heat aggregated rabbit IgG to the cytoplasm of synovial mononuclear cells. Double staining with TRITC-labelled albumin was negative. $\times 390$

Table III Findings in rabbit joints after intra-articular injections of trace amounts of homologous cathepsin D

\begin{tabular}{|c|c|c|c|c|c|c|}
\hline \multirow{2}{*}{$\begin{array}{l}\text { No. of } \\
\text { injections }\end{array}$} & \multicolumn{3}{|l|}{ Right knee } & \multicolumn{3}{|l|}{ Left knee } \\
\hline & $\begin{array}{l}\text { Injected } \\
\text { material* }\end{array}$ & Exudate & Synovium & $\begin{array}{l}\text { Injected } \\
\text { material* }\end{array}$ & Exudate & Synovium \\
\hline $\begin{array}{l}1 \\
1\end{array}$ & $6 \mu \mathrm{g}$ cathepsin $\mathrm{D}$ & $\mathrm{Neg}$ & $\mathrm{Neg}$ & Saline & $\mathrm{Neg}$ & $\mathrm{Neg}$ \\
\hline $\begin{array}{l}3 \\
3\end{array}$ & $6 \mu \mathrm{g}$ cathepsin $\mathrm{D}$ & Neg & Neg & Saline & $\mathrm{Neg}$ & Neg \\
\hline $\begin{array}{l}6 \\
6\end{array}$ & $6 \mu \mathrm{g}$ cathepsin $\mathrm{D}$ & Trace amounts & $\begin{array}{l}\text { Neg, some focal superficial } \\
\text { infiltrates with PMN }\end{array}$ & Saline & $\mathrm{Neg}$ & $\mathrm{Neg}$ \\
\hline $\begin{array}{l}12 \\
12\end{array}$ & $6 \mu \mathrm{g}$ cathepsin $\mathrm{D}$ & Trace amounts & $\begin{array}{l}\text { Focal superficial infiltrates } \\
\text { with PMN and a few } \\
\text { mononuclear cells }\end{array}$ & Saline & $\mathrm{Neg}$ & $\mathrm{Neg}$ \\
\hline
\end{tabular}


the signs of acute synovitis, with initially focal and later diffuse infiltration of PMNs. Hyperplasia of the lining layer begins after 3 injections and reaches a maximum after 6 injections. Electron microscope studies (Watanabe and others, 1976) have shown that synoviocytes of $\mathrm{M}(=\mathrm{A})$ and $\mathrm{F}(=\mathrm{B})$ types are involved in this hyperplasia. After 12 injections the PMN infiltrations extending into the deepest layers of the membrane are largely replaced by mononuclear infiltrations of a partly nodular nature (germinal centres were only observed after 27 or more injections! Velvart and others, 1976b). Under the optical microscope the mononuclear cells appear as small lymphocytes, macrophages, and plasma cells. The results of electron microscope studies of these cells will be published elsewhere (Watanabe and others, 1976).

Other symptoms of synovitis observed are dilated capillaries and venules, oedema, and predominantly superficial exudation of fibrinous material, possibly accompanied by patchy necrosis of the lining layer. Later on, thrombosis of some of the smaller arteries and arterioles occurs. After 12 injections the cartilage shows the first signs of superficial degeneration, including incipient pannus formation. The histological and immunohistochemical changes characterizing this Fab2 arthritis leave no doubt that Fab2 when injected acts as an antigen and, with specific natural homoreactants, forms immune complexes that are subject to phagocytosis. Although agglutinators and homoreactants do not precipitate IgG fragments but only agglutinate them and form in vitro for instance little chromatographically visible immune complexes (Mandy, 1967), the intra-articular injection of Fab2 results in a prompt and massive infiltration of PMNs as well as in the phagocytosis of IgG, homoreactants to Fab2, and RF-like antibodies. After 12 injections plasmacell syinthesis of homoreactants to Fab2 and of antigammaglobulins can be shown in the synovial membrane; these react with homologous and heterologous IgG. These findings constitute evidence of the formation of biologically active immune complexes.

As will be seen from Table II, both PMNs and macrophages of the exudate and synovial membrane are involved in the phagocytosis of the immune complexes, as well as the $M$ cells of the lining layer, though to a smaller extent. The intensive phagocytotic activity of these cells has also been shown under the electron microscope (Watanabe and others, 1976). Since the animals were sacrificed 24 hours after the last injection, most of the PMNs showed signs of degeneration and were often themselves phagocytosed by mononuclear phagocytes, including the $M$ cells of the lining layer (Watanabe and others, 1976). The histological and immunological changes accompanying the synovitis due to autologous cathepsin D
Fab2 described here are similar not only to the synovial changes reported by Rawson and others (1969) after injections of homologous and autologous papain Fab but also to those seen in animals actively immunized by intra-articular injections of foreign antigens (Belovic and Kinsella, 1973; Dumonde and Glynn, 1962) or passively immunized by intravenous antibody injections (Hollister, Liang, and Mannik, 1973). They also resemble the changes observed after intra-articular application of immune complexes (Hollister and others, 1973; Rawson and Torralba, 1967). The PMN reaction (Hollister and others, 1973; Rawson and Torralba, 1967), the phagocytosis of specific immune complexes by the PMNs and macrophages of the exudate (Belovic and Kinsella, 1973; Hollister and others, 1973) and tissues (Hollister and others, 1973) and by cells of the lining layer (Hollister and others, 1973; Kinsella, Baum, and Ziff, 1969), as well as the stimulation of the synthesis of specific antibodies to the injected antigen by some of the synovial plasma cells (Doble and others, 1973; Graham and Shanon, 1972; Jasin and Ziff, 1969), are identical in our experimental model. Autologous cathepsin Fab2 thus appears to act in the joint as a fairly potent antigen responsible for humoral immunological changes. Whether it also sets immunological processes of delayed type in motion and what significance in that event such processes have are matters on which our studies throw no light. In view of the findings with papain $F\left(a^{\prime}\right)$ recently reported by Goldberg, Lance, and Davis (1974), however, it should be emphasized that it seems unnecessary for the animals to be preimmunized with complete Freund's adjuvant for intensive synovitis to occur.

An interesting feature of Fab2 arthritis is the rapid induction of the formation of antigammaglobulins of RF type. After 6 intra-articular injections of autologous cathepsin D Fab2, a slight increase in ' $R F$ ' could be shown with anti-D Ripley; after 12 injections this increase was statistically significant. The extra-articular immunization of rabbits with Fab2 fragments leads similarly to the formation of 'RF' (Fehr, Velvart, and Böni, 1976). Since the Fab2 fragments possess no antigenic determinants for RF, it can be assumed that antibody formation is not directly induced but takes place via immune complexes between Fab2 and homoreactants.

Synovitis induced by autologous cathepsin D Fab2 in animals thus has a striking similarity with RA synovitis not only histologically but also immunologically. In RA synovitis, phagocytosis of RF-IgG immune complexes by exudate and tissue phagocytes, and the formation of RF in the joint capsule, play an important part (Munthe and Natvig, 1972). Direct immunofluorescence studies (without pepsin treatment of the tissue (Natvig, 1966) indicate that the locally produced and 
phagocytosed 'RF' is of IgM type, but they fail to show whether IgG-type RF is also synthesized. Chromatography of some animal sera has, however, shown 'RF' eluting in the IgG range (Fehr and others, 1976).

Recent findings concerning cathepsin D Fab2 in man provide a further parallel with our animal model. In RF-positive RA the titres of these antibodies in the serum and joint puncture fluid have been shown to be significantly higher than in control groups. They are phagocytosed in the same way by cells of the joint exudate (Velvart, Fehr, and Böni, 1976a), and are synthesized in the synovial membrane in both seronegative and seropositive RA (Artmann, 1974).

This work was supported in part by a research grant from 'Eidgenössische Rheumakommission' of the Swiss Public Health Service. The authors are grateful to Mrs. H. Engler and Miss M. Hold for excellent technical assistance, and to Mr. E. Boyce and Miss E. Feller for help in preparing the manuscript.

\section{References}

ANDREws, P. (1965) Biochem. J., 96, 595 (The gel-filtration behaviour of proteins related to their molecular weight over a wide range)

ArTmanN, G. (1974) 'Agglutinators; antibodies against hidden antigenic sites of IgG in the serum, synovial fluid and synovial tissue of patients with rheumatic diseases'. Dissertation, Zurich University

BARRETT, A. J. (1967) Biochem. J., 104, 601 (Lysosomal acid proteinase of rabbit liver)

Belovic, B., AND Kinsella, T. D. (1973) Ann. rheum. Dis., 32, 167 (Immunofluorescent demonstration of an intraarticular antigen-antibody complex in experimental arthritis of the guinea-pig)

BrandtZaEG, P. (1973a) Scand. J. Immunol., 2, 273 (Conjugates of immunoglobulin G with different fluorochromes. I. Characterization by anionic-exchange chromatography)

(1973b) Ibid., 2, 333 (Conjugates of immunoglobulin G with different fluorochromes. II. Specific and non-specific binding properties)

Doble, A., Dorling, J., Glynn, L. E., WebB, J. A., ANd Wilcox, J. H. (1973) Brit. J. exp. Path., 54, 646 (Experimental arthritis, light and electron microscope studies of antigen and antibody using horseradish peroxidase as antigen)

DumONDE, D. C., AND GLYNN, L. E. (1962) Ibid., 43, 373 (The production of arthritis in rabbits by an immunological reaction to fibrin)

FeHR, K. (1971) 'Gammaglobulin G fragment antigens produced by digestion of IgG with intracellular protease and their possible relation to inflammation and rheumatoid factor formation in rheumatoid arthritis' in 'Rheumatoid Arthritis. Pathogenic Mechanisms and Consequences in Therapeutics', eds. W. Müller, H. G. Harwerth, and K. Fehr, p. 383. Academic Press, London and New York

- , AND LoSpalluto, J. (1971) J. Immunol., 107, 814 (Exposure of hidden antigenic determinants in human IgG by digestion with spleen proteases)

,-- , AND ZIFF, M. (1970) Ibid., 105, 973 (Degradation of immunoglobulin G by lysosomal acid proteases)

- Velvart, M., AND BöNI, A. (1974) Adv. clin. Pharmacol., 6, 64 (Digestion of autologous IgG by acid lysosomal protease (cathepsin D) and its role in immune complex formation and inflammation)

$-,-1,-1976$ ) (in preparation) Experimental arthritis in rabbits induced by intraarticular injection of autologous Fab2 produced by cathepsin D. III. Serologic and immunologic findings)

Goldberg, V. M., LaNCE, E. M., AND Davis, P. (1974) Arthr. and Rheum. 17, 993 (Experimental immune synovitis in the rabbit: relative roles of cell mediated and humoral immunity)

Graham, R. C. Jr., AND Shanon, S. L. (1972) Amer.J. Path. 67, 69 (Peroxidase arthritis. I. An immunologically mediated inflammatory response with ultra-structural cytochemical localization of antigen and specific antibody)

Henry, J. (1974) 'Clinical Chemistry. Principles and Techniques,' 2nd ed., p. 422. Harper and Row, New York

Hijmans, W., Schuit, H. R. E., AND Klein, F. (1969) Clin. exp. Immunol., 4, 457 (An immunofluorescence procedure for detection of intracellular immunoglobulins)

Hollister, J. B., Liang, G. C., AND MANNIK, M. (1973) Arthr. and Rheum. 16, 10 (Immunologically induced acute synovitis in rabbits: Studies of immune complexes in synovial fluid)

JASIN, H. E., AND ZIFF, M. (1969) J. Immunol., 102, 355 (Immunoglobulin and specific antibody synthesis in a chronic inflammatory focus. Antigen-induced synovitis)

Kinsella, T. D., BAUM, J., AND ZIFF, M. (1969) Clin. exp. Immunol. 4, 256 (Immunofluorescent demonstration of an IgG- $\beta_{1} C$ complex in synovial lining cells of rheumatoid synovial membrane)

LitwIN, S. D. (1968) Fed. Proc. 27, 2, Abstr. 2895 (Agglutinators reacting with pepsin digested human gammaglobulin found in sera of subhuman primates)

MANDY, W. J. (1966a) J. Immunol., 95, 501 (A new serum factor in normal rabbits. I. Identification and characterization) (1966b) Ibid., 97, 876 (A new serum factor in normal rabbits. II. Reaction of buried antigenic determinants revealed after papain digestion)

- (1967) Ibid., 99, 815 (A new serum factor in normal rabbits. III. Specificity for antigenic determinants uncovered by papain or pepsin digestion)

_, AND LEWIS, F. B. (1966) Nature (Lond.) 212, 791 (Homoreactant: a new serum factor in normal rabbits) 
- Woolsey, M. E., AND Lewis, F. B. (1968) J. Immunol., 100, 15 (A new serum factor in normal rabbits. IV. Occurrence in neonatal rabbit sera)

Munthe, E., and Natvig, J. B. (1972) Scand. J. Immunol., 1, 217 (Complement fixing intracellular complexes of IgG rheumatoid factor in rheumatoid plasma cells)

Natvig, J. B. (1966) Acta path. microbiol. scand., 66, 369 (Heterogeneity of anti-gamma-globulin factors detected by pepsin-digested human gamma-G-globulin)

Osterland, C. K., Harboe, M., AND KunKel, H. G. (1966) J. Immunol., 97, 438 (Anti-gamma-globulin factors in human sera revealed by enzymatic splitting of anti-Rh-antibodies)

Quismorio, F. P., Owen, B., Rawson, A. J., Abelson, N. M., and Hollander, T. L. (1968) Arthr. and Rheum., 11, 113 (Abstr.) (Synovitis from injected IgG fragments in rheumatoid patients)

Rawson, A. J., Quismorio, F. P., ANd Abelson, N. M. (1969) Amer. J. Path., 54, 95 (The induction of synovitis in the normal rabbit with $\mathrm{Fab}$ )

- , AND Torralba, T. P. (1967) Arthr. and Rheum., 10, 44 (Induction of proliferative synovitis in rabbits by intraarticular injection of immune complexes)

Velvart, M., Fehr, K., AND BöNI, A. (1976a) (in preparation) (Immunkomplexe, Cathepsin D Agglutinatoren und Rheumafaktoren in Phagolysosomen von Gelenkexsudat-Leukozyten bei verschiedenen rheumatischen Krankheiten)

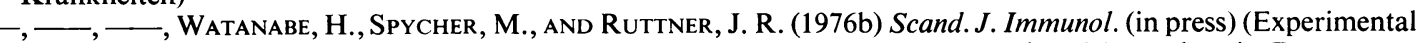
arthritis in rabbits, induced by intraarticular injection of autologous Fab2 produced by cathepsin D.

II. Histologic and immunohistochemical findings in long term studies)

Waller, M., AND BLAYLOCK, K. (1966) J. Immunol. 97, 438 (Further studies on the anti-globulin-factors in human serum to the pepsin digested fragment of the Ri-anti Rh-antibody)

Watanabe, H., Spycher, M., Rüttner, J. R., Fehr, K., Velvart, M., and Böni, A. (1976) Scand.J Immunol. (in press) (Ultrastructural studies of rabbit synovitis induced by autologous IgG fragments. I. Proliferation of the lining cells)

WeSTON, P. D. (1969) Immunology, 17, 421 (A specific antiserum to lysosomal cathepsin D) 